\section{Zinc Sulfate and Sugar Alcohol Zinc Sprays at Critical Stages to Improve Apple Fruit Quality}

\author{
Yong Zhang ${ }^{1,4}$, Chunxia $\mathrm{Fu}^{1}$, Yujing Yan ${ }^{1}$, Yan'an Wang ${ }^{1,5}$, \\ Ming $\mathrm{Li}^{2,4}$, Meixiang Chen ${ }^{2}$, Jianping Qian², Xinting Yang ${ }^{2,5}$, \\ and Shuhan Cheng ${ }^{3}$
}

AdDitional INDEX wORDs. Malus $\times$ domestica, color, soluble sugar, vitamin $\mathrm{C}$

SUMMARY. This research was initiated to determine the response of apple (Malus $\times$ domestica) fruit quality to sprays of zinc sulfate $\left(\mathrm{ZnSO}_{4}\right)$ and sugar alcohol zinc. Two apple cultivars Fuji and Gala were evaluated, the leaf zinc $(\mathrm{Zn})$ concentration of which were about $14.3 \mathrm{mg} \cdot \mathrm{kg}^{-1}$ dry weight without $\mathrm{Zn}$ deficiency symptoms. The trees were sprayed with $\mathrm{ZnSO}_{4}$ and sugar alcohol zinc separately during four different developmental stages: 2 weeks before budbreak (P1), 3 weeks after bloom (P2), the termination of spring shoot growth (P3), and 4 weeks before harvest (P4). The fruit was harvested at maturity and analyzed for fruit quality and fruit $\mathrm{Zn}$ concentration. Zinc sprays during the four different developmental stages increased $\mathrm{Zn}$ concentration of peeled and washed fruit at harvest, without phytotoxicity. The treatments at stages P2 and P4 increased average fruit weight of 'Gala' and 'Fuji', respectively. The treatments at stages $\mathrm{Pl}$ and $\mathrm{P} 4$ increased the fruit firmness of 'Gala', while the treatments at stages P1 and P2 increased the fruit firmness of 'Fuji'. The treatments at stages $\mathrm{P} 1, \mathrm{P2}$, and $\mathrm{P} 4$ increased the soluble sugar and vitamin $\mathrm{C}$ of 'Gala' fruit, while the treatments at all the stages increased the soluble sugar and vitamin $\mathrm{C}$ of 'Fuji'. And the effects of sugar alcohol zinc were equal and more pronounced than those of $\mathrm{ZnSO}_{4}$. Thus, $\mathrm{Zn}$ sprays at critical periods can improve fruit quality of apple trees, which show no $\mathrm{Zn}$ deficiency symptoms with leaf $\mathrm{Zn}$ concentration less than $15 \mathrm{mg} \cdot \mathrm{kg}^{-1}$ dry weight.

Z inc is essential for the healthy growth and reproduction of all organisms (Broadley et al., 2007) and plays a key role in catalytic, regulatory, and structural functions in plants, including carbohydrate metabolism, photosynthesis, and sugar and starch synthesis (Hacisalihoglu et al., 2003). The apple is among the four most popular fruits in the world, and as an essential fruit for human health, high fruit quality is important. $\mathrm{Zn}$ deficiencies affect production and

Funding for this research was provided by the National Public Benefit (Agricultural) Research Foundation of China (200903044), National Key Technology Research and Development Program of the Ministry of Science and Technology of China (2011BAD21B06), the National Public Benefit (Agricultural) Research Foundation of China (201103003), and the National High Technology Research and Development Program of China (2011AAl00703)

${ }^{1}$ State Key Laboratory of Crop Biology/College of Life science, Shandong Agricultural University, Tai'an, Shandong, 271018, People Republic of China

${ }^{2}$ National Engineering Research Center for Information Technology in Agriculture, Beijing, 100097, People Republic of China

${ }^{3}$ College of Information Science and Engineering, Shandong Agricultural University, Tai'an, Shandong, 271018, People Republic of China

${ }^{4}$ These authors contributed equally to this work as the joint first authors.

${ }^{5}$ Corresponding author. E-mail: wyaapple@126.com, yangxt@nercita.org.cn. quality of all crops, particularly major staple crops; apple cultivars tend to be highly susceptible to $\mathrm{Zn}$ deficiency, and the symptoms associated with $\mathrm{Zn}$ deficiency have been well documented (Alloway, 2008). Similar to other micronutrients, $\mathrm{Zn}$ is not a mobile element within the plant, thus deficiency symptoms are first observed in the youngest leaves (Fageria et al., 2003). Zn deficiency results in reduced leaf and shoot size and photosynthetic rates, ultimately influencing the apple yield and quality (Wang and Jin, 2005; Yan et al., 2010). About $50 \%$ of the cultivated soils of the world (Sadeghzadeh and Rengel, 2011 ), and $51.1 \%$ of the soils in China are $\mathrm{Zn}$ deficient (Zou et al., 2008). The amelioration of $\mathrm{Zn}$ deficiency through soil $\mathrm{Zn}$ application is limited by many factors, such as the high soil $\mathrm{pH}$, low soil moisture, and low organic matter (Sarkar and Wynjones, 1982; Sarong et al., 1989), which negatively impact the absorption and upward transport of $\mathrm{Zn}$ in the roots; therefore, this method of application requires a long treatment duration, and the effects are not always obvious (Swietlik, 1999). In contrast, $\mathrm{Zn}$ application on the aerial parts of plants is an effective, rapid, and economic method for ameliorating $\mathrm{Zn}$ deficiency (Swietlik, 2002a).

As $\mathrm{Zn}$ application is widely practiced, many cultivation areas show no $\mathrm{Zn}$ deficiency. However, it has remained unclear whether continuing the supply of $\mathrm{Zn}$ could increase fruit quality. Although many fruit trees were found to be $\mathrm{Zn}$ deficient based on leaf $\mathrm{Zn}$ analysis $\left(12-13 \mathrm{mg} \cdot \mathrm{kg}^{-1}\right.$ dry weight of leaves), these trees exhibited no $\mathrm{Zn}$ deficiency (Swietlik, 2002a). Furthermore, the orchards grown on $\mathrm{Zn}$-amended fields produce fruit of varying quality as a consequence of differences in the $\mathrm{Zn}$ nutrition status (Alloway, 2008); thus, it is essential to study the relationship between $\mathrm{Zn}$ and apple quality.

Many researchers reported that $\mathrm{Zn}$ nutrition is closely related to fruit quality. In Brazil, the foliar application of $\mathrm{ZnSO}_{4}$ and the use of $\mathrm{Zn}$ tablets increased the size of coffee beans [Coffea arabica (Poltronieri et al., 2011)]. In Iran, combining the placement of $\mathrm{ZnSO}_{4}$ in holes at the base of the trees with foliar applications increased the $\mathrm{Zn}$ concentration of apple fruit tissue from 0.7 to $1.5 \mathrm{mg} \cdot \mathrm{kg}^{-1}$ (Malakouti, 2001); the foliar application of $\mathrm{Zn}$ also increased the number and yield of fruit compared with the control treatment (Roosta and Hamidpour, 2011). However, studies about the effects on fruit quality of different forms of foliar $\mathrm{Zn}$ applied at different stages of apple tree growth are very few. A single

\begin{tabular}{llll}
\hline $\begin{array}{l}\text { Units } \\
\text { To convert U.S. to SI, } \\
\text { multiply by }\end{array}$ & U.S. unit & SI unit & $\begin{array}{l}\text { To convert SI to U.S., } \\
\text { multiply by }\end{array}$ \\
\hline 10 & $\%$ & $\mathrm{~g} \cdot \mathrm{kg}^{-1}$ & 0.1 \\
29.5735 & $\mathrm{fl} \mathrm{oz}$ & $\mathrm{mL}$ & 0.0338 \\
2.54 & inch $(\mathrm{es})$ & $\mathrm{cm}$ & 0.3937 \\
25.4 & inch(es) & $\mathrm{mm}$ & 0.0394 \\
0.6895 & lbf $/ \mathrm{inch}^{2}$ & $\mathrm{~N} \cdot \mathrm{cm}^{-2}$ & 1.4503 \\
28.3495 & $\mathrm{oz}$ & $\mathrm{g}$ & 0.0353 \\
1 & $\mathrm{ppm}$ & $\mathrm{mg} \cdot \mathrm{kg}^{-1}$ & 1 \\
$\left({ }^{\circ} \mathrm{F}-32\right) \div 1.8$ & ${ }^{\circ} \mathrm{F}$ & ${ }^{\circ} \mathrm{C}$ & $\left({ }^{\circ} \mathrm{C} \times 1.8\right)+32$
\end{tabular}


foliar spray of fulvic- and humic-based $\mathrm{Zn}$ compounds was equally or more effective than $\mathrm{ZnSO}_{4}$ at being absorbed by vegetative apple seedling tissue (Neilsen et al., 2005), but whether the sugar alcohol zinc is effective has not been clear. Recently, sugar compounds containing $\mathrm{Zn}$ have been advocated for use with little information to support their use. The goal of the present study was to compare the effects of the application of $\mathrm{ZnSO}_{4}$ and sugar alcohol $\mathrm{Zn}$ sprays separately at different developmental stages on apple fruit quality and make sure that whether continuing the supply of $\mathrm{Zn}$ could increase fruit quality of apple trees with no zinc deficiency symptoms.

\section{Materials and methods}

ZINC SPRAYS ON APPLE TREES. This study was conducted in 2011 and 2012 in a fruit orchard (lat. $36^{\circ} 14^{\prime} \mathrm{N}$, long. $116^{\circ} 50^{\prime} \mathrm{E}$ ) at Chaoquan Town, Feicheng Country, Tai'an, Shandong Province, China. This area is frequently subjected to periods of high summer and warm autumn temperatures, with a moderate amount of annual rainfall $(680 \mathrm{~mm})$. The weather conditions for 2011 and 2012 were typical of the recently warming climate, but the mean temperature during winter (from December to February) in $2012\left(1.34{ }^{\circ} \mathrm{C}\right)$ was lower than in $2011\left(2.79^{\circ} \mathrm{C}\right)$. The annual mean temperatures including 15.6 and $16.1^{\circ} \mathrm{C}$ in 2011 and 2012 , respectively, in this experiment area, are in a raising trend among the 30 years (from $12.3^{\circ} \mathrm{C}$ in 1984 to 16.1 ${ }^{\circ} \mathrm{C}$ in 2012). These records meet with the global warming trend (Ding et al., 2006; Yao and Li, 2012). Twelveyear-old 'Fuji' and 'Gala' apple trees on the seedling rootstock tea crabapple (Malus hupehensis) were used as the experimental materials and the trees were chosen based on the uniformity of tree size and zinc nutritional status. The leaf $\mathrm{Zn}$ concentration of the chosen trees was (mean \pm SD) $14.3 \pm$ $1.2 \mathrm{mg} \cdot \mathrm{kg}^{-1}$ dry weight, and the trees showed no symptoms of $\mathrm{Zn}$ deficiency, the usual situation in Shandong Province and elsewhere (Swietlik, 1999).

Trees of two apple tree cultivars (Gala and Fuji) were sprayed with $\mathrm{ZnSO}_{4}$ and sugar alcohol zinc (a type of zinc-chelated liquid fertilizer composed of 3\% N, 10\% sugar alcohol and 7\% Zn; Beijing Xinhefeng Agrichemical Co., Beijing, China) during four plant developmental stages in 2011 and 2012: Pl (2 weeks before budbreak), P2 (3 weeks after bloom), P3 (termination of spring shoot growth), and P4 (4 weeks before harvest). The experiment was designed as in Table 1. At 2 weeks before budbreak, apple trees have no leaves, so we sprayed $\mathrm{Zn}$ on branches. And $\mathrm{Zn}$ concentration of sprays was higher than that at the other stages.

In 2011 and 2012 we used different apple trees for both 'Gala' and 'Fuji', but the measures and analysis were same. The trees were arranged in a randomized block design with five replicates per treatment each for 'Gala' and 'Fuji', one tree per replicate, and guard trees were included between the treatments. The leaves were sprayed on the abaxial/adaxial surfaces with backpack, and the solution was allowed to drip/runoff. Five fruit were picked randomly from the outer region at the same canopy height on each side (east and west) of each tree at harvest for both 'Gala' and 'Fuji' (Harvest date of 'Gala': 29 Aug. 2011 and 23 Aug. 2012; Harvest date of 'Fuji': 20 Oct. 2011 and 17 Oct. 2012). So for each replicate, 10 fruit were picked randomly.
Fruit QUALITY meAsurements. Samples of 10 fruit per replicate were assessed for quality after washed under running distilled water and then air-dried. First, we determined length/diameter (L/D) ratio, average fruit weight, and skin color. We measured fruit length and diameter using a vernier caliper. We measured the average fruit weight using an electronic balance, and skin color was measured three times at three locations along the equator of each fruit using a portable color difference meter (HP-210; China Spec Co., Shenzhen, China). Values were recorded according to the Commission Internationale d' Éclairage (CIE, $1931)$ color space coordinates $\left(L^{*}, a^{*}\right.$, and $\left.b^{*}\right)$. The fruit firmness was measured at three equatorial regions of the peeled flesh using a penetrometer (GY-B; Top Instruments Co., Zhejiang, China), while the soluble solids were measured using a portable refractometer (PAL-1; Atago, Tokyo, Japan) on a composite juice sample collected during the pressure test.

Second, we removed the peels entirely from each of the 10 individual fruit. After removing the core, the flesh was cut into pieces and mixed well per replicate. The samples were weighed $10 \mathrm{~g}$ per replicate and immediately frozen in liquid nitrogen, and then stored at $-80{ }^{\circ} \mathrm{C}$ for determination of soluble sugar, titratable acidity, and vitamin $\mathrm{C}$ concentration. Some flesh was taken from the mixture and dried in an oven at $60{ }^{\circ} \mathrm{C}$ for determination of $\mathrm{Zn}$ concentration.

The soluble sugar concentration was determined using anthrone colorimetry (Li, 1994). The fruit flesh stored was put into boiling water for 1 $\mathrm{h}$; the extract was filtered into a volumetric flask. Anthrone-ethyl acetate

Table 1. Trials of zinc sprays on apple trees at different stages.

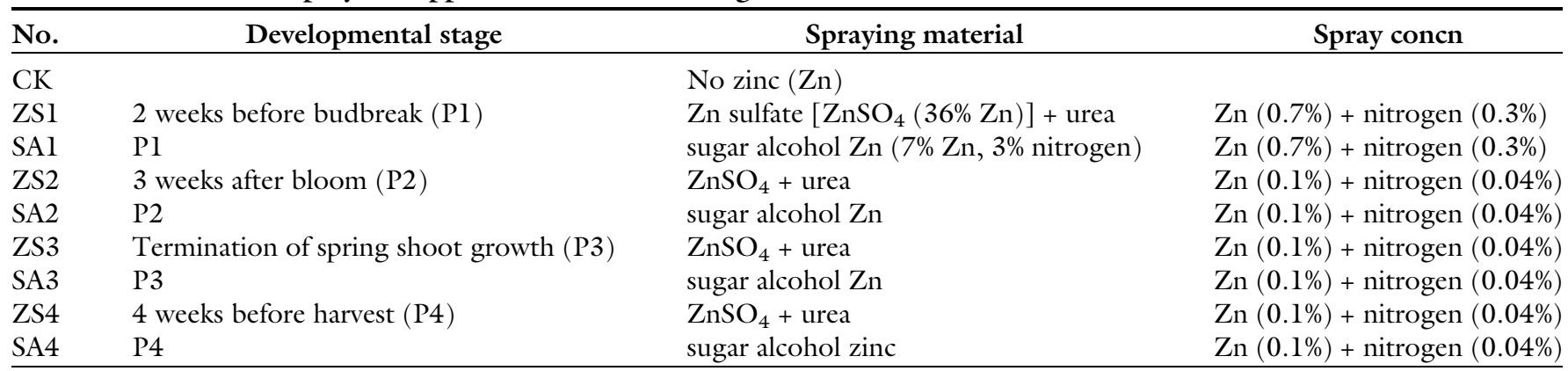


( $\mathrm{lg}$ anthrone dissolved in $50 \mathrm{~mL}$ ethyl acetate) and concentrated sulfuric acid were added to a sample of the extract in a fresh tube. The mixture was boiled for $1 \mathrm{~min}$, and the absorbance was measured at $620 \mathrm{~nm}$ using a spectrophotometer. The titratable acidity was measured using sodium hydroxide titration $(\mathrm{Li}, 1994)$. The fruit flesh stored was homogenized and poured into boiling water for $\mathrm{l} \mathrm{h}$; the extract was filtered into a volumetric flask. The extract was transferred into a breaker and titrated with sodium hydroxide up to $\mathrm{pH}$ 8.2. Acidity of fruit was reported and calculated as a percentage of hydrochloric acid concentration. The vitamin $\mathrm{C}$ concentration was determined using $\mathrm{xy}-$ lene extraction colorimetry ( $\mathrm{Li}, 1994)$. The fruit flesh ground with $2 \%$ oxalic acid. The homogenate was transferred to a volumetric flask, and 30\% $\mathrm{ZnSO}_{4}$ and $15 \%$ potassium ferrocyanide were added; the extract was filtered into a beaker. A sample of the filtrate was collected in a fresh tube, and 2,6-dichlorophenol indophenol (DCPIP) and dimethylbenzene were added. The tube was immediately vortexed for $0.5 \mathrm{~min}$, and the mixture was separated. The absorbance of the $\mathrm{xy}$ lene fraction was measured at $500 \mathrm{~nm}$ using a spectrophotometer (ultraviolet-2550; Shimadzu, Kyoto, Japan). The vitamin $\mathrm{C}$ concentration was determined as the reduction of DCPIP.

The dried fruit tissues were ground into a fine powder and weighed $2 \mathrm{~g}$ for the determination of the $\mathrm{Zn}$ concentration. The dry biomass was digested in a $4: 1(\mathrm{v}: \mathrm{v})$ mixture of nitric $\left(\mathrm{HNO}_{3}\right)$ and perchloric $\left(\mathrm{HClO}_{4}\right)$ acids for $\mathrm{l} \mathrm{h}$ at $195{ }^{\circ} \mathrm{C}$. The extracted solution was analyzed using an atomic absorption spectrophotometer (SP9400 type; England PYE Co., Cambridge, United Kingdom).

Statistical analysis. The data were preprocessed using Excel 2003 (Microsoft, Redmond, WA), and the figures were generated using SigmaPlot 10.0 (Systat Software, Erkrath, Germany). Significant differences among the treatments and the control were determined through an analysis of variance using SAS (version 8.1; SAS Institute, Cary, NC), followed by the Tukey test for multiple comparisons among the groups. The mean values were separated using the Tukey test at the $P \leq 0.05$ level of significance.

\section{Results}

EFFECTS OF $Z_{N}$ SPRAYS ON THE CROP LOAD, AVERAGE FRUIT WEIGHT AND SIZE. The crop load obtained for the control and $\mathrm{Zn}$ treatments was essentially the same, and no significant differences were found between the control and treatments in 2011 or 2012 . The crop load (mean \pm SD) was $278 \pm 25$ and $235 \pm 20$ fruit per tree for 'Gala' and 'Fuji' in 2011, respectively, and the crop load in 2012 was $242 \pm 20$ and $206 \pm 16$ fruit per tree for 'Gala' and 'Fuji', respectively. The differences in crop load between 2011 and 2012 might be the result of different weather conditions. There was no significant difference in the average fruit weight between the control and treated 'Gala' apples, except for the SA treatment at P2 in 2011 (Fig. 1A). In 2012, the P2 treatments increased the average fruit weight (Fig. 1C). Zn treatment at P4 significantly increased the average fruit weight of the 'Fuji' apples in 2011 (Fig. 1B), and the treatments at P2 and P4 in 2012 also significantly increased the average fruit weight (Fig. ID). The fruit size of the treatments and control was of no significant difference, so as the $\mathrm{L} / \mathrm{D}$ ratio (data not presented), and the mean diameter of 'Gala' and 'Fuji' fruit was 7.3 and $8.7 \mathrm{~cm}$, respectively.

EFFECTS OF $Z_{N}$ SPRAYS ON THE FRUIT COLOR DURING THE COURSE OF RIPENING. The results showed that the treatments at $\mathrm{Pl}$ and P4 significantly decreased hue angle of the 'Gala' fruit in 2011 and 2012 (Fig. $2 \mathrm{~A}$ and $2 \mathrm{C}$ ); for the 'Fuji' fruit, all the treatments resulted in decreased hue angle (Fig. 2B and 2D).

EFFECTS OF $Z_{N}$ SPRAYS ON THE FRUIT INNER QUALITY. The firmness of the 'Gala' fruit was increased in all the treatments, mainly for ZSI, SAl, SA3, ZS4, and SA4; among them the effect of the SA4 treatment was similar to that of SA3 and less pronounced than the other three treatments in 2011 (Table 2). In 2012, the ZSl, SAl, ZS4, and SA4 treatments significantly increased the firmness of the 'Gala' fruit, and about the treatments at Pl and P4 stage the effects of sugar alcohol zinc were greater than those of $\mathrm{ZnSO}_{4}$ (Table 3). In both 2011 and 2012, the treatments administered at 2 weeks before budbreak (ZSI and SAl) and at 3 weeks after bloom (ZS2 and SA2) increased the firmness of the 'Fuji' fruit, and about the treatments at P2 stage the effects of sugar alcohol zinc were greater than those of $\mathrm{ZnSO}_{4}$ (Tables 4 and 5 ).

In 2011 and 2012, the treatments administered at 2 weeks before budbreak (SAl), at 3 weeks after bloom (SA2), and at 4 weeks before harvest (ZS4 and SA4) significantly increased the soluble solids in the 'Gala' fruit, and about the treatments at $\mathrm{Pl}$ and P2 stage the effects of sugar alcohol zinc being greater than those of $\mathrm{ZnSO}_{4}$ (Tables 2 and 3). Except for $\mathrm{ZS} 2, \mathrm{ZS} 3$, and ZS4, the other treatment applications improved the soluble solids in the 'Fuji' fruit (Table 4). The results in 2012 were consistent with those in 2011 (Tables 4 and 5 ).

Except for the treatments administered during the termination of spring shoot growth (ZS3 and SA3), the other treatments significantly improved the soluble sugar concentration of the 'Gala' fruit, with the results in 2011 and 2012 being similar; about the treatments at Pl stage in 2011 and the treatments at Pl, P4 stage in 2012 the effect of sugar alcohol zinc were greater than those of $\mathrm{ZnSO}_{4}$ (Tables 2 and 3). All the treatments applied to the 'Fuji' trees increased the soluble sugar concentration of the fruit (Tables 4 and 5 ).

The treatments administered at 3 weeks after bloom (ZS2 and SA2) and at 4 weeks before harvest (SA4) decreased the titratable acid concentration of the 'Gala' fruit in 2011 (Table 2), whereas ZS2, SA2, ZS4, and SA4 decreased the titratable acid concentration of the 'Gala' fruit in 2012 (Table 3). The effects on the 'Fuji' apples were greater at the later stage of development. About the treatments at P2, P3 stage in 2011, and the treatments at P2, P4 stage in 2012 the effects of sugar alcohol zinc treatment were greater than those of the $\mathrm{ZnSO}_{4}$ treatment (Tables 4 and 5 ).

Except for the treatments administered during the termination of the spring shoot growth (ZS3 and SA3), the other treatments significantly improved the vitamin $\mathrm{C}$ concentration of the 'Gala' fruit in 2011 and 2012. About the treatments at P2, P4 stage in 2011, and the treatments at P2 stage in 2012 the effects of the administration of sugar alcohol zinc were greater than those of 


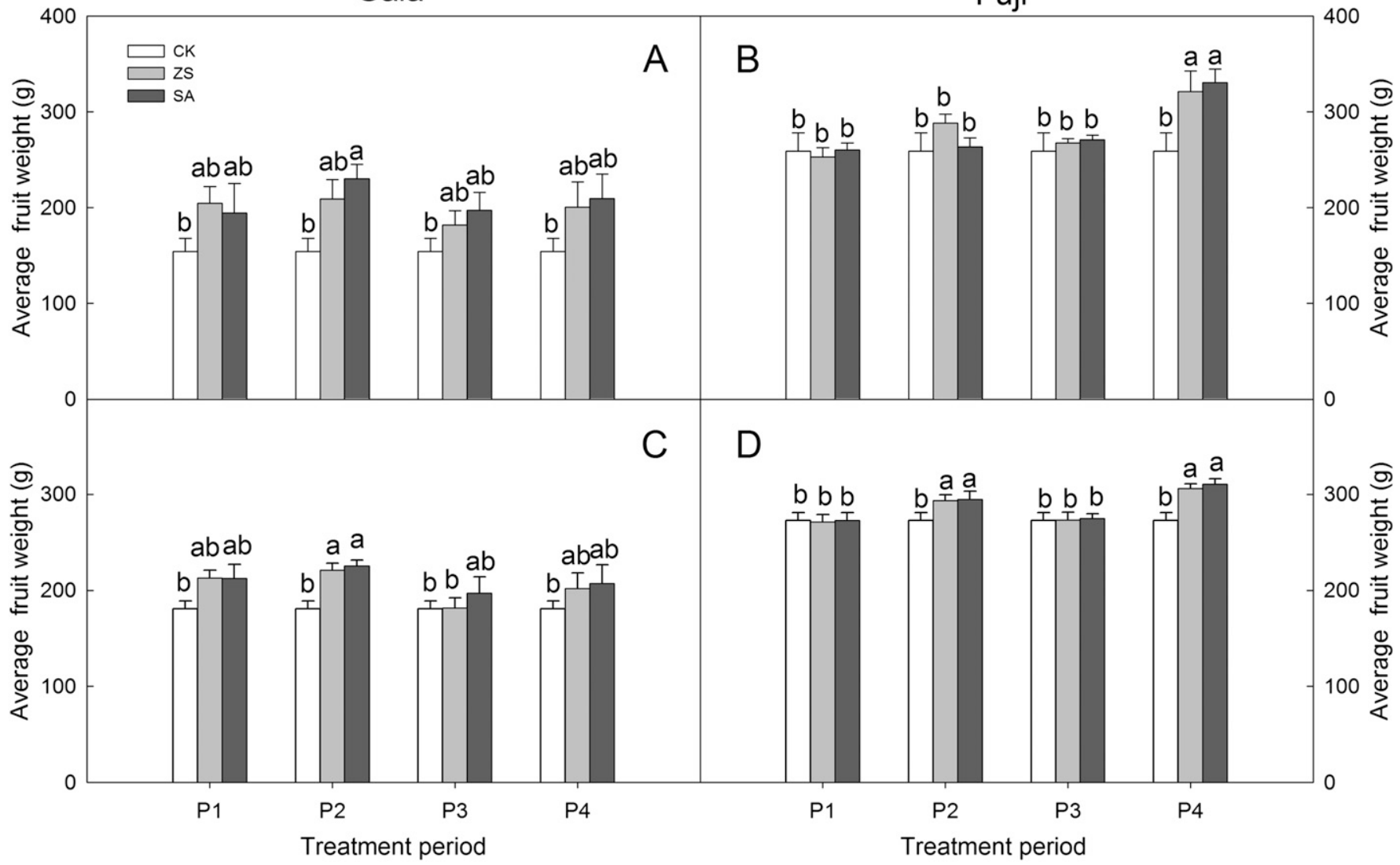

Fig. 1. Effects of zinc sulfate and sugar alcohol zinc treatments at different development stages on the average fruit weight of apple: (A) 'Gala' in 2011, (B) 'Fuji' in 2011, (C) 'Gala' in 2012, (D) 'Fuji' in 2012 (ZS = leaves sprayed with zinc sulfate, $\mathrm{SA}=$ leaves sprayed with sugar alcohol zinc, $\mathrm{Pl}=$ before budbreak, $\mathrm{P} 2=3$ weeks after bloom, $\mathrm{P} 3=$ termination of spring shoot growth, $\mathrm{P} 4=4$ weeks before harvest). Each bar is mean \pm SD. Different letters above the bars indicate significant differences via Tukey's test at $P<0.05 ; 1 \mathrm{~g}=0.0353 \mathrm{oz}$.

$\mathrm{ZnSO}_{4}$ (Tables 2 and 3). For 'Fuji', the ZS2, SA2, SA3, ZS4, and SA4 treatments significantly increased the vitamin C concentration in 2011. Except for ZSI and ZS3, the other treatments significantly increased the vitamin $C$ concentration in 2012 (Tables 4 and 5 ).

EFFECTS OF $Z_{N}$ SPRAYS ON THE FRUIT $Z$ N CONCENTRATION. The treatments administered at the four developmental stages increased the $\mathrm{Zn}$ concentration in the 'Gala' fruit, and the effects of sugar alcohol zinc were greater than those of $\mathrm{ZnSO}_{4}$ in both 2011 and 2012 (Fig. 3A and 3C). In contrast, the effects were different for the 'Fuji' fruit: the $\mathrm{Zn}$ concentration was higher in the treatments with $\mathrm{ZnSO}_{4}$ at 2 weeks before budbreak $(\mathrm{Pl})$ and at 3 weeks after bloom (P2); the $\mathrm{Zn}$ concentration was higher in the treatments with sugar alcohol at the termination of the spring shoot growth (P3) and at 4 weeks before harvest (P4) (Fig. 3B and 3D).

\section{Discussion}

Zn sprays on 'Gala' and 'Fuji' trees administrated at 2 weeks before budbreak, 3 weeks after bloom, the termination of spring shoot growth, and 4 weeks before harvest increased fruit quality. Zinc sprays administrated 2 weeks before budbreak may promote pollination because zinc was required for better pollination (Sharma et al., 1990). Zinc sprays administrated 3 weeks after bloom may promote cell division and development of young fruit because zinc was required for cell division (MacDonald, 2000). Zinc sprays administrated 4 weeks before harvest may increase the photosynthetic ability because $\mathrm{Zn}$ plays an important role as a structural and regulatory cofactor for a wide range of enzymes, such as carbonic anhydrase (Vallee and Auld, 1990) and aldolase (Gijsen et al., 1996), in synthesis of assimilates (Wang and Jin, 2005). The effects of $\mathrm{Zn}$ application during the termination of the spring shoot growth showed weaker than the other three stages may be due to flower bud differentiation and growth of new shoot competed with fruit for nutrition (Goldschmidt, 1999).

It was reported that foliar $\mathrm{Zn}$ application after blooming could increase the $\mathrm{Zn}$ concentration of fruit (Hipps and Davies, 2001; Neilsen and Neilsen, 2002). The results of the present study were consistent with those of previous reports. Interestingly, the treatments at stages $\mathrm{P} 1, \mathrm{P} 2$, and $\mathrm{P} 4$ increased the quality of 'Gala' fruit, while the treatments at all the stages increased the quality of 'Fuji' fruit, which might have resulted from the delayed ripening of the 'Fuji' fruit compared with the 'Gala' apples, and the specific mechanism involved in this process requires further study. Thus, fertilizer application strategies should be recommended differently according to different cultivars. We recommend that $\mathrm{Zn}$ should be sprayed 


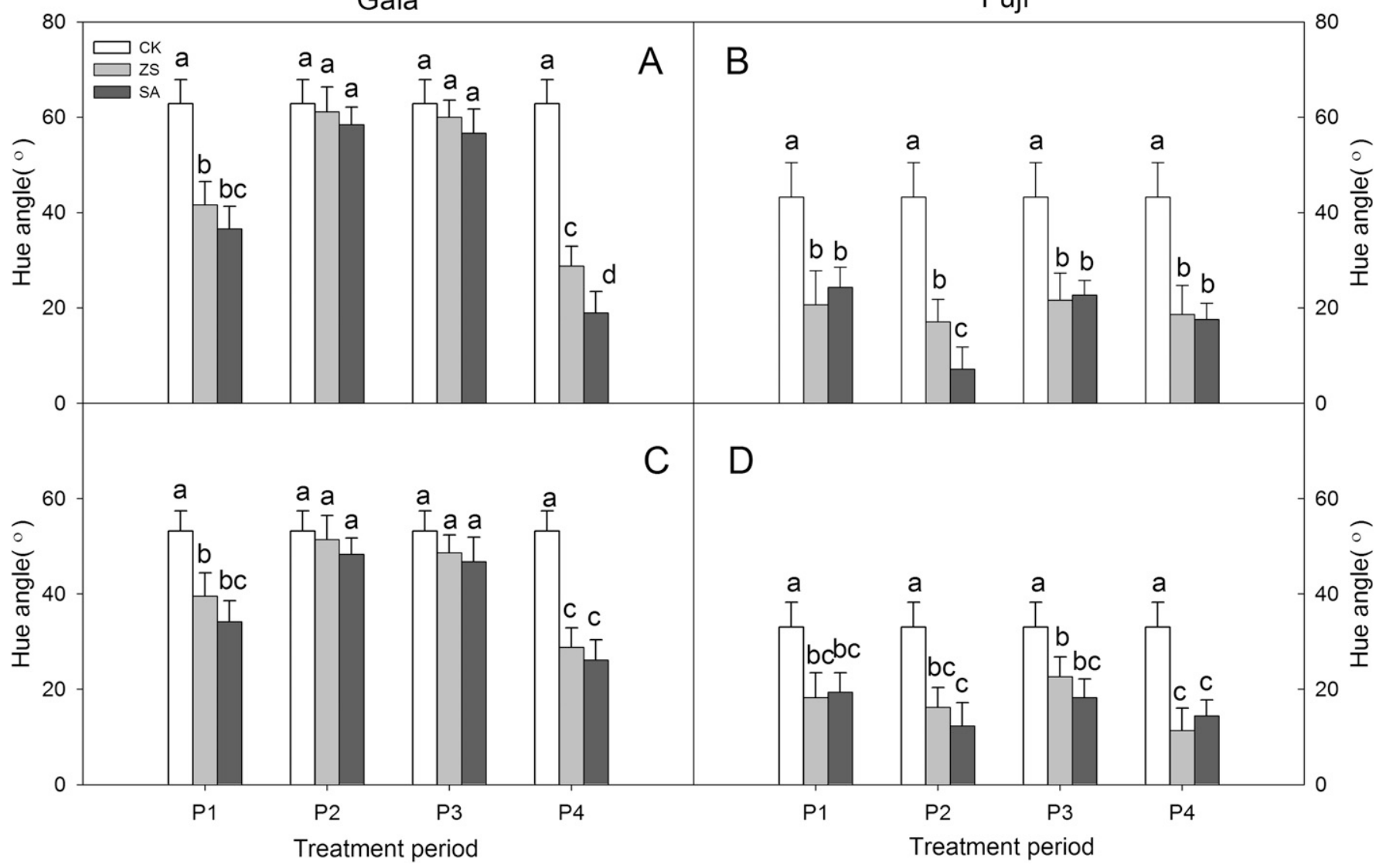

Fig. 2. Effects of zinc sulfate and sugar alcohol zinc treatments at different development stages on the color parameter, hue angle, of apple fruit: (A) 'Gala' fruit in 2011, (B) 'Fuji' fruit in 2011, (C) 'Gala' fruit in 2012, (D) 'Fuji' fruit in 2012 (ZS = leaves sprayed with zinc sulfate, $\mathrm{SA}=$ leaves sprayed with sugar alcohol zinc, $\mathrm{Pl}=$ before budbreak, $\mathbf{P 2}=\mathbf{3}$ weeks after bloom, $\mathrm{P3}=$ termination of spring shoot growth, $\mathrm{P} 4=4$ weeks before harvest). Each bar is mean \pm SD. Different letters above the bars indicate significant differences via Tukey's test at $P<0.05$.

Table 2. Effects of zinc sulfate and sugar alcohol zinc treatments at different development stages on the internal quality of 'Gala' apple fruit in 2011.

\begin{tabular}{|c|c|c|c|c|c|}
\hline Treatments $^{\mathrm{z}}$ & 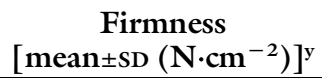 & $\begin{array}{l}\text { Soluble solids } \\
{[\text { mean } \pm \text { SD }(\%)]^{y}}\end{array}$ & $\begin{array}{c}\text { Soluble sugar } \\
{[\text { mean } \pm \text { SD }(\%)]}\end{array}$ & $\begin{array}{c}\text { Titratable } \\
{[\text { mean } \pm \text { SD }(\%)]}\end{array}$ & $\begin{array}{c}\text { Vitamin C } \\
{\left[\text { mean } \pm \text { SD }\left(\mathrm{mg} \cdot \mathrm{kg}^{-1}\right)\right]^{y}}\end{array}$ \\
\hline $\mathrm{CK}$ & $35.8 \pm 2.1 \mathrm{~d}^{\mathrm{x}}$ & $12.6 \pm 0.46 c$ & $9.41 \pm 0.27 \mathrm{f}$ & $0.158 \pm 0.009 \mathrm{a}$ & $109 \pm 7 \mathrm{~d}$ \\
\hline ZSI & $48.5 \pm 2.0 \mathrm{a}$ & $12.4 \pm 0.15 \mathrm{c}$ & $11.2 \pm 0.85 \mathrm{~cd}$ & $0.146 \pm 0.003 \mathrm{ab}$ & $125 \pm 3.4 \mathrm{c}$ \\
\hline SAl & $49.8 \pm 4.0 \mathrm{a}$ & $14.8 \pm 0.43 a$ & $14.3 \pm 0.57 \mathrm{a}$ & $0.150 \pm 0.006 \mathrm{ab}$ & $133 \pm 4.4 \mathrm{bc}$ \\
\hline ZS2 & $40.0 \pm 2.5 \mathrm{bcd}$ & $13.0 \pm 0.36 \mathrm{c}$ & $10.8 \pm 0.43 \mathrm{de}$ & $0.142 \pm 0.005 \mathrm{bc}$ & $126 \pm 1.4 \mathrm{bc}$ \\
\hline SA 2 & $39.0 \pm 1.6 \mathrm{bcd}$ & $15.1 \pm 0.53 a$ & $11.5 \pm 0.17 \mathrm{~cd}$ & $0.143 \pm 0.001 \mathrm{bc}$ & $138 \pm 1.3 \mathrm{ab}$ \\
\hline ZS4 & $48.3 \pm 3.6 \mathrm{a}$ & $14.3 \pm 0.21 \mathrm{ab}$ & $12.1 \pm 0.03 b c$ & $0.145 \pm 0.004 \mathrm{ab}$ & $134 \pm 4.3 \mathrm{bc}$ \\
\hline SA4 & $44.9 \pm 1.6 \mathrm{abc}$ & $14.3 \pm 0.31 \mathrm{ab}$ & $13.2 \pm 0.59 \mathrm{ab}$ & $0.131 \pm 0.005 \mathrm{c}$ & $147 \pm 0.7 \mathrm{a}$ \\
\hline
\end{tabular}

${ }^{\mathrm{z}} \mathrm{CK}=$ no zinc $(\mathrm{Zn}) ; \mathrm{ZSI}=$ sprayed at 2 weeks before budbreak $(\mathrm{Pl}$ stage $)$ with $\mathrm{Zn}$ sulfate $\left(\mathrm{ZnSO}_{4}\right) ; \mathrm{SA} 2=$ sprayed at $\mathrm{Pl}$ stage with sugar alcohol $\mathrm{Zn} ; \mathrm{ZS} 2=$ sprayed at 3 weeks after bloom $(\mathrm{P} 2$ stage $)$ with $\mathrm{ZnSO}_{4} ; \mathrm{SA} 2=$ sprayed at $\mathrm{P} 2$ stage with sugar alcohol $\mathrm{Zn} ; \mathrm{ZS} 3=$ sprayed at the termination of spring shoot growth $(\mathrm{P} 3$ stage $)$ with $\mathrm{ZnSO}_{4} ; \mathrm{SA} 3=$ sprayed at P3 stage with sugar alcohol $\mathrm{Zn} ; \mathrm{ZS} 4=$ sprayed at 4 weeks before harvest (P4 stage) with $\mathrm{ZnSO}_{4} ; \mathrm{SA}_{4}=$ sprayed at P4 stage with sugar alcohol Zn.

${ }^{y} 1 \mathrm{~N} \cdot \mathrm{cm}^{-2}=1.4503 \mathrm{lbf} /$ inch $^{2}, 1 \mathrm{~g} \cdot \mathrm{kg}^{-1}=0.1 \%, 1 \mathrm{mg} \cdot \mathrm{kg}^{-1}=1 \mathrm{ppm}$.

${ }^{x}$ Mean values followed by the same letter in the column are not significantly different via Tukey's test at $P<0.05$.

on 'Gala' at one of stages P1, P2, and $\mathrm{P} 3$ and $\mathrm{Zn}$ should be sprayed on 'Fuji' at one of all the stages. But for both cultivars, we found that the effects of zinc application at the stage P4 was greater than that at other stages in most quality parameters. So the stage $\mathrm{P} 4$ is the best one to increased fruit quality for both 'Gala' and 'Fuji'.
The soil organic matter plays a critical role in the solubility of $\mathrm{Zn}$ and transport into the plant roots (Cakmak, 2008), and $\mathrm{Zn}$ chelation improves the uptake and transport of 
Table 3. Effects of zinc sulfate and sugar alcohol zinc treatments at different development stages on the internal quality of 'Gala' apple fruit in 2012 .

\begin{tabular}{|c|c|c|c|c|c|}
\hline Treatments $^{\mathrm{z}}$ & 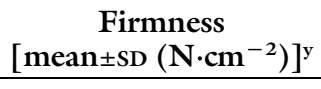 & $\begin{array}{l}\text { Soluble solids } \\
{[\text { mean } \pm \text { SD }(\%)]^{y}}\end{array}$ & $\begin{array}{l}\text { Soluble sugar } \\
{[\text { mean } \pm \text { SD }(\%)]}\end{array}$ & $\begin{array}{c}\text { Titratable } \\
{[\text { mean } \pm \text { SD }(\%)]}\end{array}$ & $\begin{array}{c}\text { Vitamin C } \\
{\left[\text { mean } \pm \text { SD }\left(\mathrm{mg} \cdot \mathrm{kg}^{-1}\right)\right]^{\mathrm{y}}}\end{array}$ \\
\hline $\mathrm{CK}$ & $35.6 \pm 1.2 \mathrm{c}^{\mathrm{x}}$ & $12.3 \pm 0.4 \mathrm{~d}$ & $9.4 \pm 0.1 \mathrm{~d}$ & $0.160 \pm 0.004 \mathrm{a}$ & $108 \pm 3 \mathrm{e}$ \\
\hline $\mathrm{ZSI}$ & $45.7 \pm 1.0 \mathrm{~b}$ & $13.0 \pm 0.1 \mathrm{~cd}$ & $11.3 \pm 0.2 \mathrm{c}$ & $0.146 \pm 0.002 b$ & $121 \pm 3 \mathrm{~cd}$ \\
\hline SAl & $50.4 \pm 1.1 \mathrm{a}$ & $14.6 \pm 0.3 \mathrm{ab}$ & $13.8 \pm 0.1 \mathrm{a}$ & $0.147 \pm 0.003 \mathrm{ab}$ & $129 \pm 3 \mathrm{bc}$ \\
\hline ZS2 & $38.7 \pm 0.7 \mathrm{c}$ & $13.0 \pm 0.3 \mathrm{~cd}$ & $11.3 \pm 0.1 \mathrm{c}$ & $0.140 \pm 0.006 \mathrm{bc}$ & $125 \pm 2 c$ \\
\hline SA2 & $38.8 \pm 1.0 \mathrm{bc}$ & $14.8 \pm 0.5 \mathrm{a}$ & $11.8 \pm 0.3 \mathrm{bc}$ & $0.143 \pm 0.002 \mathrm{bc}$ & $135 \pm 2 \mathrm{ab}$ \\
\hline ZS4 & $46.9 \pm 0.4 b$ & $14.2 \pm 0.5 \mathrm{abc}$ & $12.2 \pm 0.2 \mathrm{~b}$ & $0.146 \pm 0.004 \mathrm{~b}$ & $134 \pm 2 \mathrm{ab}$ \\
\hline SA4 & $50.4 \pm 1.0 \mathrm{a}$ & $14.3 \pm 0.4 \mathrm{abc}$ & $13.2 \pm 0.3 \mathrm{a}$ & $0.132 \pm 0.003 \mathrm{c}$ & $140 \pm 2 \mathrm{a}$ \\
\hline
\end{tabular}

${ }^{2} \mathrm{CK}=$ no zinc $(\mathrm{Zn}) ; \mathrm{ZSI}=$ sprayed at 2 weeks before budbreak $(\mathrm{Pl}$ stage $)$ with $\mathrm{Zn}$ sulfate $\left(\mathrm{ZnSO}_{4}\right) ; \mathrm{SA} 2=$ sprayed at P1 stage with sugar alcohol $\mathrm{Zn} ; \mathrm{ZS2}=$ sprayed at 3 weeks after bloom ( $\mathrm{P} 2$ stage $)$ with $\mathrm{ZnSO}_{4} ; \mathrm{SA} 2=$ sprayed at $\mathrm{P} 2$ stage with sugar alcohol $\mathrm{Zn} ; \mathrm{ZS} 3=$ sprayed at the termination of spring shoot growth $(\mathrm{P} 3$ stage $)$ with $\mathrm{ZnSO}$; $\mathrm{SA}_{3}=$ sprayed at P3 stage with sugar alcohol $\mathrm{Zn} ; \mathrm{ZS} 4=$ sprayed at 4 weeks before harvest $\left(\mathrm{P} 4\right.$ stage) with $\mathrm{ZnSO}_{4} ; \mathrm{SA} 4=$ sprayed at $\mathrm{P} 4$ stage with sugar alcohol $\mathrm{Zn}$.

${ }^{y} 1 \mathrm{~N} \cdot \mathrm{cm}^{-2}=1.4503 \mathrm{lbf} / \mathrm{inch}^{2}, 1 \mathrm{~g} \cdot \mathrm{kg}^{-1}=0.1 \%, 1 \mathrm{mg} \cdot \mathrm{kg}^{-1}=1 \mathrm{ppm}$.

${ }^{x}$ Mean values followed by the same letter in the column are not significantly different via Tukey's test at $P<0.05$.

Table 4. Effects of zinc sulfate and sugar alcohol zinc treatment at different development stages on the internal quality of 'Fuji' apple fruit in 2011.

\begin{tabular}{|c|c|c|c|c|c|}
\hline Treatments $^{\mathrm{z}}$ & $\begin{array}{c}\text { Firmness } \\
{\left[\text { mean } \pm \text { SD }\left(\mathrm{N} \cdot \mathrm{cm}^{-2}\right)\right]^{\mathrm{y}}}\end{array}$ & $\begin{array}{l}\text { Soluble solids } \\
{[\text { mean } \pm \text { SD }(\%)]^{y}}\end{array}$ & $\begin{array}{l}\text { Soluble sugar } \\
{[\text { mean } \pm \text { SD }(\%)]}\end{array}$ & $\begin{array}{c}\text { Titratable } \\
{[\text { mean } \pm \text { SD }(\%)]}\end{array}$ & $\begin{array}{c}\text { Vitamin C } \\
{\left[\text { mean } \pm \text { SD }\left(\mathrm{mg} \cdot \mathrm{kg}^{-1}\right)\right]^{\mathrm{y}}}\end{array}$ \\
\hline CK & $31.6 \pm 1.2 \mathrm{~d}^{\mathrm{x}}$ & $12.2 \pm 0.7 \mathrm{c}$ & $10.6 \pm 0.1 \mathrm{e}$ & $0.192 \pm 0.004 \mathrm{a}$ & $98 \pm 10 c$ \\
\hline ZSI & $37.5 \pm 0.4 \mathrm{ab}$ & $15.4 \pm 0.1 \mathrm{ab}$ & $14.4 \pm 0.3 \mathrm{abc}$ & $0.191 \pm 0.011 \mathrm{a}$ & $123 \pm 7 b c$ \\
\hline SAl & $41.0 \pm 2.6 \mathrm{a}$ & $15.1 \pm 1.9 \mathrm{ab}$ & $14.8 \pm 0.1 \mathrm{ab}$ & $0.188 \pm 0.005 \mathrm{a}$ & $127 \pm 17 \mathrm{abc}$ \\
\hline $\mathrm{ZS} 2$ & $36.2 \pm 2.7 b c$ & $13.0 \pm 1.0 \mathrm{bc}$ & $12.3 \pm 0.3 \mathrm{~d}$ & $0.176 \pm 0.006 \mathrm{ab}$ & $147 \pm 11 \mathrm{ab}$ \\
\hline SA2 & $41.8 \pm 0.9 \mathrm{a}$ & $15.9 \pm 1.6 \mathrm{a}$ & $14.3 \pm 0.2 \mathrm{abc}$ & $0.157 \pm 0.005 \mathrm{~cd}$ & $149 \pm 17 \mathrm{ab}$ \\
\hline ZS4 & $35.0 \pm 2.0 \mathrm{bcd}$ & $14.0 \pm 1.0 \mathrm{abc}$ & $15.5 \pm 0.2 \mathrm{a}$ & $0.163 \pm 0.007 \mathrm{bcd}$ & $152 \pm 5 \mathrm{ab}$ \\
\hline SA4 & $32.0 \pm 1.3 \mathrm{~cd}$ & $14.7 \pm 0.8 \mathrm{ab}$ & $13.7 \pm 0.6 \mathrm{bc}$ & $0.148 \pm 0.009 \mathrm{~d}$ & $159 \pm 12 \mathrm{a}$ \\
\hline
\end{tabular}

${ }^{2} \mathrm{CK}=$ no zinc $(\mathrm{Zn}) ; \mathrm{ZSI}=$ sprayed at 2 weeks before budbreak ( $\mathrm{Pl}$ stage) with $\mathrm{Zn}$ sulfate $\left(\mathrm{ZnSO}_{4}\right) ; \mathrm{SA} 2=$ sprayed at $\mathrm{Pl}$ stage with sugar alcohol $\mathrm{Zn} ; \mathrm{ZS2}=$ sprayed at 3 weeks after bloom (P2 stage) with $\mathrm{ZnSO}_{4} ; \mathrm{SA} 2=$ sprayed at $\mathrm{P} 2$ stage with sugar alcohol $\mathrm{Zn} ; \mathrm{ZS} 3=$ sprayed at the termination of spring shoot growth $(\mathrm{P} 3$ stage $)$ with $\mathrm{ZnSO}{ }_{4} ; \mathrm{SA}_{3}=$ sprayed at P3 stage with sugar alcohol $\mathrm{Zn} ; \mathrm{ZS} 4=$ sprayed at 4 weeks before harvest $\left(\mathrm{P} 4\right.$ stage) with $\mathrm{ZnSO}_{4} ; \mathrm{SA} 4=$ sprayed at $\mathrm{P} 4$ stage with sugar alcohol $\mathrm{Zn}$.

${ }^{1} 1 \mathrm{~N} \cdot \mathrm{cm}^{-2}=1.4503 \mathrm{lbf} / \mathrm{inch}^{2}, 1 \mathrm{~g} \cdot \mathrm{kg}^{-1}=0.1 \%, 1 \mathrm{mg} \cdot \mathrm{kg}^{-1}=1 \mathrm{ppm}$.

${ }^{x}$ Mean values followed by the same letter in the column are not significantly different via Tukey's test at $P<0.05$.

Table 5. Effects of zinc sulfate and sugar alcohol zinc treatment at different development stages on the internal quality of 'Fuji' apple fruit in 2012.

\begin{tabular}{|c|c|c|c|c|c|}
\hline Treatments $^{\mathrm{z}}$ & 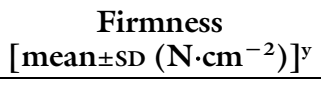 & $\begin{array}{l}\text { Soluble solids } \\
{[\text { mean } \pm \text { SD }(\%)]^{\mathrm{y}}}\end{array}$ & $\begin{array}{c}\text { Soluble sugar } \\
{[\text { mean } \pm \text { SD }(\%)]}\end{array}$ & $\begin{array}{c}\text { Titratable } \\
{[\text { mean } \pm \text { SD }(\%)]}\end{array}$ & $\begin{array}{c}\text { Vitamin C } \\
{\left[\text { mean } \pm \text { SD }\left(\mathrm{mg} \cdot \mathrm{kg}^{-1}\right)\right]^{\mathrm{y}}}\end{array}$ \\
\hline $\mathrm{CK}$ & $32.3 \pm 0.8 \mathrm{~d}^{\mathrm{x}}$ & $12.1 \pm 0.6 \mathrm{c}$ & $12.1 \pm 0.3 \mathrm{e}$ & $0.192 \pm 0.003 \mathrm{a}$ & $107 \pm 4 \mathrm{~d}$ \\
\hline SAl & $41.5 \pm 1.5 \mathrm{ab}$ & $15.0 \pm 1.2 \mathrm{a}$ & $14.8 \pm 0.1 \mathrm{a}$ & $0.191 \pm 0.004 \mathrm{ab}$ & $125 \pm 8 b c$ \\
\hline $\mathrm{ZS} 2$ & $36.7 \pm 2.7 \mathrm{c}$ & $12.8 \pm 0.7 \mathrm{bc}$ & $13.3 \pm 0.3 \mathrm{~d}$ & $0.180 \pm 0.005 \mathrm{bc}$ & $129 \pm 5 \mathrm{bc}$ \\
\hline SA2 & $41.8 \pm 1 \mathrm{a}$ & $15.7 \pm 1.4 \mathrm{a}$ & $14.1 \pm 0.2 \mathrm{~b}$ & $0.161 \pm 0.008 \mathrm{de}$ & $128 \pm 5 \mathrm{bc}$ \\
\hline ZS4 & $35.4 \pm 2.1 \mathrm{~cd}$ & $14.2 \pm 0.8 \mathrm{abc}$ & $13.5 \pm 0.3 \mathrm{~cd}$ & $0.165 \pm 0.005 \mathrm{~d}$ & $139 \pm 3 \mathrm{ab}$ \\
\hline SA4 & $32.1 \pm 1.2 \mathrm{~d}$ & $14.9 \pm 0.6 \mathrm{ab}$ & $14.0 \pm 0.2 \mathrm{bc}$ & $0.153 \pm 0.005 \mathrm{e}$ & $149 \pm 7 \mathrm{a}$ \\
\hline
\end{tabular}

${ }^{\mathrm{z}} \mathrm{CK}=$ no zinc $(\mathrm{Zn}) ; \mathrm{ZSI}=$ sprayed at 2 weeks before budbreak (P1 stage) with $\mathrm{Zn}$ sulfate $\left(\mathrm{ZnSO}_{4}\right) ; \mathrm{SA} 2=$ sprayed at $\mathrm{Pl}$ stage with sugar alcohol $\mathrm{Zn} ; \mathrm{ZS} 2=$ sprayed at 3 weeks after bloom $(\mathrm{P} 2$ stage $)$ with $\mathrm{ZnSO}_{4} ; \mathrm{SA} 2=$ sprayed at $\mathrm{P} 2$ stage with sugar alcohol $\mathrm{Zn} ; \mathrm{ZS} 3=$ sprayed at the termination of spring shoot growth $(\mathrm{P} 3$ stage $)$ with $\mathrm{ZnSO}$; $\mathrm{SA} 3=$

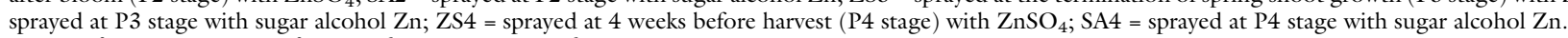

${ }^{y} 1 \mathrm{~N} \cdot \mathrm{cm}^{-2}=1.4503 \mathrm{lbf} /$ inch $^{2}, 1 \mathrm{~g} \cdot \mathrm{kg}^{-1}=0.1 \%, \mathrm{l} \mathrm{mg} \cdot \mathrm{kg}^{-1}=1 \mathrm{ppm}$.

${ }^{x}$ Mean values followed by the same letter in the column are not significantly different via Tukey's test at $P<0.05$.

$\mathrm{Zn}$ in plants (Obrador et al., 2003). In the present study, the effects of sugar alcohol zinc were greater than those of $\mathrm{ZnSO}_{4}$ in some results about firmness, soluble solids, soluble sugar, titratable acid, vitamin $\mathrm{C}$, and $\mathrm{Zn}$ concentration, potentially resulting from the $\mathrm{Zn}$ chelation of sugar alcohols to generate sugar alcohol Zn.
The results of our field experiments showed that the quality of the fruit from apple trees without $\mathrm{Zn}$ deficiency symptoms was much increased by the foliar application of 


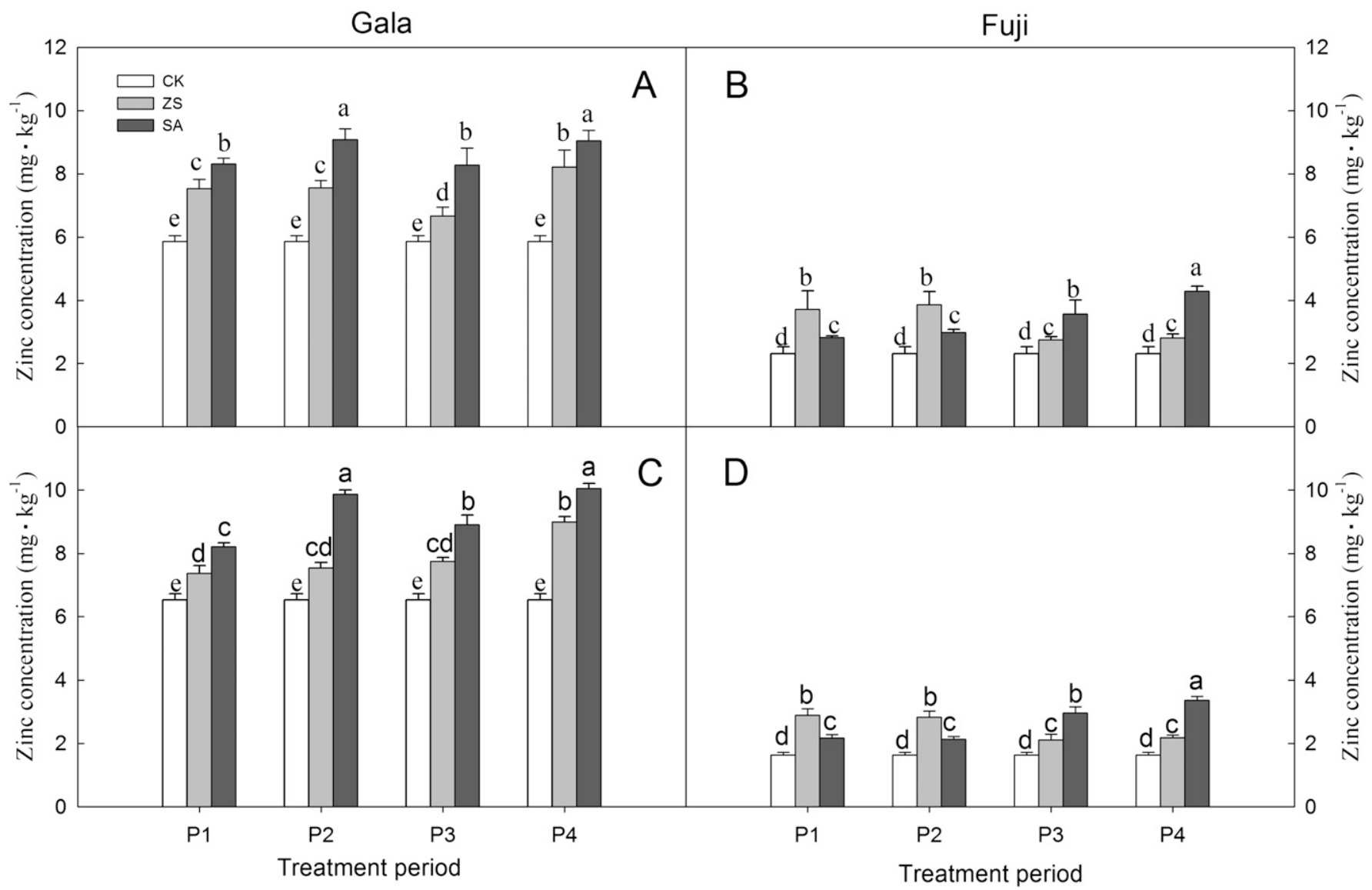

Fig. 3. Effects of zinc sulfate and sugar alcohol zinc treatments at different development stages on the zinc concentration of the apple fruit: (A) 'Gala' fruit in 2011, (B) 'Fuji' fruit in 2011, (C) 'Gala' fruit in 2012, (D) of 'Fuji' fruit in 2012 (ZS = leaves sprayed with zinc sulfate, $\mathrm{SA}=$ leaves sprayed with sugar alcohol zinc, $\mathbf{P} \mathbf{1}=$ before budbreak, $\mathbf{P 2}=2 \mathrm{weeks}$ after bloom, $\mathbf{P} 3=$ termination of spring shoot growth, $\mathrm{P} 4=4$ weeks before harvest). Each bar is mean \pm SD. Different letters above the bars indicate significant differences via Tukey's test at $P<0.05 ; 1 \mathrm{mg} \cdot \mathrm{kg}^{-1}=1 \mathrm{ppm}$.

Zn. Thus, it is inappropriate to supply $\mathrm{Zn}$, according to whether the trees exhibit $\mathrm{Zn}$ deficiency. The leaf $\mathrm{Zn}$ concentration may determine whether to supply $\mathrm{Zn}$; however, the reported normal range of leaf $\mathrm{Zn}$ concentration is controversial. $\mathrm{Zn}$ concentrations in plants typically range from 30 to $100 \mathrm{mg} \cdot \mathrm{kg}^{-1}$ dry weight, depending on the species (Fageria et al., 2003). It has been reported that the standard $\mathrm{Zn}$ concentration in apple leaves was $30-80 \mathrm{mg} \cdot \mathrm{kg}^{-1}$ dry weight (Li et al., 1987), whereas the normal range of apple leaf $\mathrm{Zn}$ concentration was also reported to be 15-200 mg. $\mathrm{kg}^{-1}$ dry weight (Neilsen and Neilsen, 2003; Shear and Faust, 1980; Swietlik, 2002b); another study reported that the normal range of apple leaf $\mathrm{Zn}$ concentration was $35-50$ $\mathrm{mg} \cdot \mathrm{kg}^{-1}$ dry weight (Stiles and Reid, 1991). Therefore, the suitable concentration of leaf $\mathrm{Zn}$ for trees is uncertain. In our study, the $\mathrm{Zn}$ toxicity to leaves and fruit was not observed, so the $\mathrm{Zn}$ concentration of spraying solution was suitable. Based on our data for 2011 and 2012, $\mathrm{Zn}$ sprays are required for improving the apple quality if the leaf $\mathrm{Zn}$ concentration is less than $15 \mathrm{mg} \cdot \mathrm{kg}^{-1}$ dry weight, despite a lack of $\mathrm{Zn}$ deficiency symptoms. And sugar alcohol zinc sprays were equally or more effective than $\mathrm{ZnSO}_{4}$ sprays.

\section{Conclusions}

Although the apple trees showed no $\mathrm{Zn}$ deficiency symptoms and the leaf $\mathrm{Zn}$ nutrition was in a low level, continuing $\mathrm{Zn}$ sprays on these trees was required to increase fruit quality. A single spray of sugar alcohol zinc was equally or more effective than $\mathrm{ZnSO}_{4}$ at being absorbed by apple fruit tissue and improving fruit quality for apple trees grown under field conditions. This study may provide a good strategy for increasing fruit quality of apple trees which shows no $\mathrm{Zn}$ deficiency symptoms and leaf $\mathrm{Zn}$ concentration is less than $15 \mathrm{mg} \cdot \mathrm{kg}^{-1}$ dry weight. In consideration of the costs, we recommend that apple growers spray $\mathrm{ZnSO}_{4}$ or sugar alcohol zinc, with $0.1 \% \mathrm{Zn}$ and $0.04 \%$ nitrogen in the spraying solution, on the abaxial/adaxial surfaces of leaves with backpack to runoff at 4 weeks before harvest.

\section{Literature cited}

Alloway, B.J. 2008. Zinc in soils and crop nutrition. 2nd ed. International Zinc Assn., Brussels, Belgium.

Broadley, M.R, P.J. White, J.P. Hammond, I. Zelko, and A. Lux. 2007. Zinc in plants. New Phytol. 173:677-702.

Cakmak, I. 2008. Enrichment of cereal grains with zinc: Agronomic or genetic biofortification? Plant Soil 302:1-17.

Commission Internationale d' Éclairage. 1931. Proceedings of the eighth session, Cambridge, England, Bureau Central de la CIE, Paris, France. 
Ding, M., S.Z. Peng, and J.M. Zhao. 2006. Nearly 53 years climatic changes at tai'an and its impacts on the development of fruits. J. Taishan Univ. 28:70-73.

Fageria, N.K., N.A. Slaton, and V.C. Baligar. 2003. Nutrient management for improving lowland rice productivity and sustainability. Adv. Agron. 80:63-152.

Gijsen, H.J., L. Qiao, W. Fitz, and C.H. Wong. 1996. Recent advances in the chemoenzymatic synthesis of carbohydrates and carbohydrate mimetics. Chem. Rev. 96:443-474.

Goldschmidt, E.E. 1999. Carbohydrate supply as a critical factor for citrus fruit development and productivity. HortScience 34:1020-1024.

Hacisalihoglu, G., J.J. Hart, Y.H. Wang, I. Cakmak, and L.V. Kochian. 2003. Zinc efficiency is correlated with enhanced expression and activity of zinc-requiring enzymes in wheat. Plant Physiol. 131: 595-602.

Hipps, N.A. and M.J. Davies. 2001. Effects of foliar zinc applications at different times in the growing season on tissue zinc concentrations, fruit set, yield and grade out of culinary apple trees. Acta Hort. 564:145-151.

Li, X.X. 1994. Fresh fruit and vegetable quality and analysis method (in Chinese). China Agricultural Press, Beijing, China.

Li, G.L., R.Y. Su, and J. Shen. 1987. Studies on the nutritional ranges in some deciduous fruit trees (in Chinese). Acta Hort. Sinica 14:81-89.

MacDonald, R.S. 2000. The role of zinc in growth and cell proliferation. J. Nutr. 130:1500S-1508S

Malakouti, M.J. 2001. The effects of balanced fertilization and zinc application on improving apple yield, quality, and reducing browning incidence. Acta Hort. 564:153-158.
Neilsen, G.H., E.J. Hogue, D. Neilsen, and P. Bowen. 2005. Postbloom humicand fulvic-based zinc sprays can improve apple zinc nutrition. HortScience 40: 205-208.

Neilsen, G.H. and D. Neilsen. 2002. Effect of foliar $\mathrm{Zn}$, form and timing of $\mathrm{Ca}$ sprays on fruit $\mathrm{Ca}$ concentration in new apple cultivars. Acta Hort. 594:435443.

Neilsen, G.H. and D. Neilsen. 2003. Nutritional requirements of apple, p. 276302. In: D.C. Ferree and I.J. Warrington (eds.). Apples: Botany, production and uses. CABI, Oxfordshire, UK

Obrador, A., J. Novillo, and J.M. Alvarez. 2003. Mobility and availability to plants of two zinc sources applied to a calcareous soil. Soil Sci. Soc. Amer. J. 67:564-572.

Poltronieri, Y., H.E.P. Martinez, and P.R Cecon. 2011. Effect of zinc and its form of supply on production and quality of coffee beans. J. Sci. Food Agr. 91:24312436 .

Roosta, H.R. and M. Hamidpour. 2011. Effects of foliar application of some macro- and micro-nutrients on tomato plants in aquaponic and hydroponic systems. Sci. Hort. 129:396-402.

Sadeghzadeh, B. and Z. Rengel. 2011. Zinc in soils and crop nutrition, $\mathrm{p}$. 335-375. In: M.J. Hawkesford and P. Barraclough (eds.). The molecular and physiological basis of nutrient use efficiency in crops. Wiley-Blackwell, Oxford, UK.

Sarkar, A. and R. Wynjones. 1982. Effect of rhizosphere $\mathrm{pH}$ on the availability and uptake of $\mathrm{Fe}, \mathrm{Mn}$ and $\mathrm{Zn}$. Plant Soil 66:361-372.

Sarong, L.Q., D.R. Bouldin, and W.S. Reid. 1989. Total and labile zinc concentrations in water extracts of rhizosphere and bulk soils of oats and rice. Commun. Soil Sci. Plant Anal. 20:271-289.
Sharma, P.N., C. Chatterjee, S.C. Agarwala, and C.P. Sharma. 1990. Zinc deficiency and pollen fertility in maize (Zea mays). Plant Soil 124:221-225.

Shear, C.B. and M. Faust. 1980. Nutritional ranges in deciduous tree fruits and nuts. Hort. Rev. 2:142-163.

Stiles, W.C. and W.S. Reid. 1991. Orchard nutrition management. Cornell Coop. Ext., Ithaca, NY.

Swietlik, D. 1999. Zinc nutrition in horticultural crops. Hort. Rev. 23:109-180.

Swietlik, D. 2002a. Zinc nutrition of fruit trees by foliar sprays. Acta Hort. 594: 123-129.

Swietlik, D. 2002b. Zinc nutrition of fruit crops. HortTechnology 12:45-50.

Vallee, B.L. and D.S. Auld. 1990. Zinc coordination, function, and structure of zinc enzymes and other proteins. Biochemistry 29:5647-5659.

Wang, H. and J.Y. Jin. 2005. Photosynthetic rate, chlorophyll fluorescence parameters, and lipid peroxidation of maize leaves as affected by zinc deficiency. Photosynthetica 43:591-596.

Yan, Z.G., Y.Z. Zhang, Y.H. Zhang, Y.A. Wang, F.S. Zhang, and H.R. Shu. 2010. Effects of zinc fertilization on the dynamics accumulation and distribution of dry matter and zinc in apple trees. Plant Nutr. Fert. Sci. 16:1402-1409. (In Chinese).

Yao, Q. and X. Li. 2012. Analysis on climate variation rules of tai'an in recent 30 years. Scientific J. Earth Sci. 2:77-82.

Zou, C., X. Gao, R. Shi, X. Fan, and F. Zhang. 2008. Micronutrient deficiencies in crop production in China, p. 127-148. In: B.J. Alloway (ed.). Micronutrient deficiencies in global crop production. Springer, Dordrecht, The Netherlands. 